\title{
Pengaruh Profitabilitas, Asset Tangibility, Tingkat Pertumbuhan, dan Non-Debt Tax Shield Terhadap Struktur Modal serta Pengaruhnya Terhadap Nilai Perusahaan (Studi Kasus Pada Perusahaan Manufaktur Asia Tenggara)
}

\author{
Dimita Purba ${ }^{1}$, Lamria Sagala ${ }^{2}$, Rintan Saragih ${ }^{3}$ \\ ${ }^{1,2,3}$ Dosen Fakultas Ekonomi Universitas Methodist Indonesia
}

\begin{abstract}
This study aims to determine what factors determine the capital structure and firm value of manufacturing companies listed on the stock exchanges of countries that are members of the Association of South East Asian Nations (ASEAN). The operationalization of the variables used in this study include Return on Assets, Tangibility Assets, Growth Rate, Non-Debt Tax Shield, and Tobin's Q. Meanwhile, from various empirical studies conducted, different results were obtained regarding the value of the company. So that it is tested again on all factors that affect the capital structure and also the value of the company
\end{abstract}

Keywords : Struktur Modal, Nilai Perusahaan, Return on Asset, Asset Tangibility, Growth Rate, Non-Debt Tax Shield

Abstrak

Penelitian ini bertujuan untuk mengetahui faktor-faktor apa saja yang menentukan struktur modal dan nilai perusahaan pada perusahaan manufaktur yang terdaftar di bursa efek negara-negara yang tergabung dalam asosiasi ASEAN (Association of South East Asian Nations). Operasionalisasi variabel yang digunakan dalam penelitian ini antara lain Return on Asset, Asset Tangibility, Tingkat Pertumbuhan, Non-Debt Tax Shield, Debt to Equity Ratio dan Tobin's Q. Sementara itu dari berbagai studi empiris yang dilakukan, diperoleh hasil yang berbeda-beda mengenai nilai perusahaan. Sehingga dilakukan pengujian kembali terhadap semua faktor yang mempengaruhi struktur modal dan juga nilai perusahaan.

Kata Kunci : Struktur Modal, Nilai Perusahaan, Return on Asset, Asset Tangibility, Tingkat Pertumbuhan, Non-Debt Tax Shield

\section{PENDAHULUAN}

Investor dalam melakukan investasi membutuhkan berbagai informasi yang dapat dijadikan sebagai sinyal untuk menilai prospek perusahaan seperti melihat nilai perusahaan yaitu dengan menganalisis laporan keuangan.

Nilai perusahaan sering dikaitkan dengan harga saham perusahaan tersebut. Harga saham yang tinggi bisa membuat nilai perusahaan juga tinggi. Dengan nilai perusahaan yang tinggi akan membuat pasar percaya bahwa prospek perusahaan di masa depan akan bagus. (Brigham dan Houston, 2006).

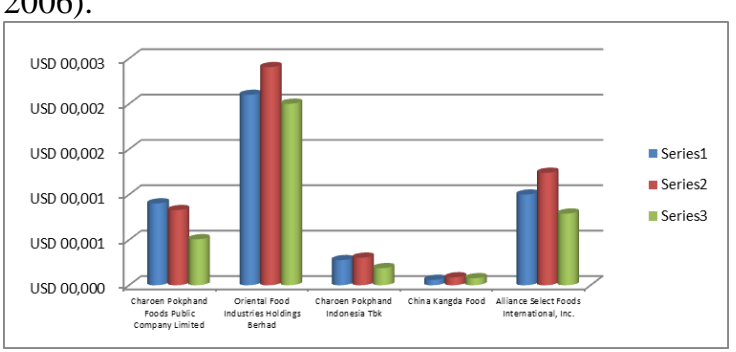

Gambar 1.1. Diagram Harga Saham Perusahaan Manufaktur beberapa Negara di Kawasan Asia Tenggara periode 2013-2015
Penelitian ini bertujuan untuk mengetahui faktor-faktor apa saja yang menentukan struktur modal pada perusahaan yang terdaftar di bursa efek negara-negara yang tergabung dalam asosiasi ASEAN (Association of South East Asian Nations). Penelitian ini fokus pada negara di kawasan Asia Tenggara karena sejak krisis ekonomi 2008 pusat kekuatan ekonomi dunia negara-negara barat yaitu Eropa dan Amerika Utara perlahan bergeser ke Asia. Di Asia sendiri, salah satu zona perekonomian yang berkembang pesat adalah Asia Tenggara.

Studi empiris menunjukkan hasil yang berlawanan mengenai pengaruh struktur modal terhadap nilai perusahaan. Kelompok peneliti yang mendukung yaitu penelitian yang dilakukan oleh (Hamidy, 2014; Masidonda, 2013) yang menyimpulkan bahwa struktur modal berpengaruh positif terhadap nilai perusahaan, sedangkan penelitian yang dilakukan oleh (Sujono, 2010; Sumiati, 2011) menyimpulkan bahwa struktur modal berpengaruh negatif terhadap nilai perusahaan. 


\section{KAJIAN LITERATUR}

\section{Nilai Perusahaan}

Nilai perusahaan merupakan persepsi investor terhadap tingkat keberhasilan perusahaan yang dapat dikaitkan dengan harga saham dan profitabilitas. Menurut Brigham dan Houston (2006) nilai perusahaan merupakan harga yang bersedia dibayar oleh calon pembeli apabila perusahaan tersebut dijual. Nilai perusahaan merupakan nilai pasar atas surat berharga hutang dan ekuitas pemegang saham yang beredar. Adapun tujuan yang ingin dicapai perusahaan tersebut adalah untuk memaksimalkan nilai pemegang saham. Nilai pemegang saham akan meningkat apabila diikuti dengan peningkatan nilai perusahaan, yang ditandai dengan tingkat pengembalian investasi yang tinggi kepada para pemegang saham.

Menurut Rakhimsyah dan Barbara (2011) nilai perusahaan yang dibentuk melalui indikator nilai pasar saham sangat dipengaruhi oleh peluang - peluang investasi. Adanya peluang investasi dapat memberikan sinyal positif tentang pertumbuhan perusahaan di masa yang akan datang, sehingga akan meningkatkan harga saham.

Nilai perusahaan merupakan net present value dari cash flow yang diharapkan dan discount rate pengembalian yang mencerminkan baik risiko perusahaan dan financing mix yang digunakan. Tujuan normatif perusahaan adalah memaksimumkan nilai perusahaan yang dikemukakan oleh Ross et. al., (2005 : 14) "The goal of financial management is to maximize the shareholder's wealth by taking action that incrase the current value per share of exiting stock of the firm" yang diartikan tujuan manajemen keuangan yaitu untuk memaksimumkan kemakmuran pemegang saham dengan mengambil tindakan pada peningkatan nilai per lembar saham sekarang dari saham yang ada. Tujuan memaksimumkan nilai perusahaan tersebut berhubungan dengan keputusan keuangan, sehingga setiap keputusan sudah selayaknya ditunjukkan dengan tindakan yang dapat meningkatkan harga saham perusahaan.

$$
\begin{aligned}
\text { Tobin's Q }= & \frac{(\text { OS X P })+(D+I)-C A}{\text { Total Asset }} \\
\text { Dimana: OS } & =\text { Outstanding Share } \\
\text { P } & =\text { Stock Price } \\
\text { D } & =\text { Total Debt } \\
\text { I } & =\text { Total Inventory } \\
\text { CA } & =\text { Current Asset } \\
\text { TA } & =\text { Total Asset }
\end{aligned}
$$

\section{Struktur Modal}

Menurut Wild et.al, (2005) struktur modal merupakan komposisi pendanaan antara ekuitas (pendanaan sendiri) dan utang pada suatu perusahaan. Keputusan pendanaan perusahaan merupakan salah satu aspek yang berpengaruh dalam menciptakan nilai bagi perusahaan. Struktur modal tercermin pada utang jangka panjang dan unsur modal sendiri, dimana kedua unsur tersebut merupakan dana permanen atau dana jangka panjang. Struktur modal diproksikan dengan Debt to Equity Ratio (DER). Debt to Equity Ratio (DER) adalah perbandingan antara total utang dengan total modal. Debt to Equity Ratio (DER) digunakan untuk mengukur tingkat penggunaan utang terhadap total shareholder's equity yang dimiliki perusahaan. Menurut Mardiyati, et. al, (2012) kebijakan hutang merupakan kebijakan perusahaan tentang seberapa jauh sebuah perusahaan menggunakan pendanaan utang.

Menurut Horne dan Wachoviz (dalam Suharli, 2005), "Debt to equity is computed by simply dividing the total debt of the firm (including current liabilities) by its shareholders equity". Debt to Equity Ratio (DER) menunjukkan tingkat utang perusahaan, perusahaan dengan utang yang besar mempunyai biaya utang yang besar pula. Hal tersebut menjadi beban bagi perusahaan yang dapat menurunkan tingkat kepercayaan investor. Para investor cenderung menghindari saham - saham yang memiliki Debt to Equity Ratio (DER) yang tinggi.

$$
\text { Debt to Equity Ratio (DER) }=\frac{\text { Total Utang }}{\text { Total Ekuitas }} \times 100 \%
$$

\section{Variabel yang Mempengaruhi Struktur Modal}

\section{Profitabilitas}

Profitabilitas sebagai tolak ukur dalam menentukan alternatif pembiayaan, namun cara untuk menilai profitabilitas suatu perusahaan yaitu tergantung pada laba dan aktiva yang dibagikan yaitu laba bersih setelah pajak (net income) yang berasal dari kegiatan operasi perusahaan di bagi total aktiva (total assets). Menurut Silaban dan Siahaan (2011) profitability merupakan kemampuan perusahaan untuk menghasilkan laba. Perolehan profit merupakan ukuran keberhasilan kinerja finansial perusahaan. Ukuran kinerja finansial memberikan petunjuk apakah strategi perusahaan, implementasi dan pelaksanaannya memberikan kontribusi atau tidak kepada peningkatan profit perusahaan, dimana dalam penelitian ini diproksikan dengan Return on Assets (ROA).

Rasio profitabilitas yang diukur dengan Return on Assets (ROA) merupakan pengukuran kemampuan perusahaaan secara keseluruhan di dalam menghasilkan keuntungan dengan jumlah keseluruhan aktiva yang tersedia di dalam perusahaan. ROA digunakan untuk melihat tingkat efisiensi operasi perusahaan secara keseluruhan. Semakin tinggi rasio proitabilitas ini, maka semakin baik suatu perusahaan. 
Return on Assets $(\mathrm{ROA})=\frac{\text { Laba bersih setelah pajak }}{\text { Total Aktiva }} \times 100 \%$

\section{Asset Tangibility}

Trade off theory menjelaskan bahwa asset tangibility berpengaruh positif terhadap struktur modal, dan juga penelitian Indrajaya et. al., (2011) mengemukakan hasil penelitiannya yang menyimpulkan bahwa asset tangibility berpengaruh positif signifikan terhadap struktur modal. Asset tangibility merupakan salah satu faktor yang paling penting dalam hal untuk menentukan keputusan terhadap struktur modal, karena besarnya fixed asset dapat dijadikan sebagai jaminan kepada kreditor (Joni dan Lina, 2010).

Indikator yang digunakan untuk variabel asset tangibility adalah aktiva tetap (fixed asset) dibagi dengan total aktiva (total asset).

\section{Asset Tangibility $=\frac{\text { Fixed Asset }}{\text { Total Asset }} \times 100 \%$}

\section{Tingkat Pertumbuhan}

Tingkat pertumbuhan merupakan merupakan salah satu faktor yang mempengaruhi struktur modal suatu perusahaan, dimana perusahaan yang mempunyai tingkat pertumbuhan yang tinggi maka perusahaan biasanya lebih cenderung senang untuk menggunakan utang yang besar. Karena perusahaan menilai mampu untuk membayar seluruh kewajibannya kepada kreditor, sehingga perusahaan yang mempunyai tingkat pertumbuhan yang tinggi akan lebih mudah memperoleh pendanaan dari pihak eksternal yaitu kreditor. . Tingkat pertumbuhan perusahaan dapat mempengaruhi kepercayaan kreditor terhadap perusahaan dan kesediaan pemodal untuk memberikan pendanaan melalui utang jangka panjang (Firnanti, 2011).

Dapat disimpulkan bahwa semakin tinggi tingkat pertumbuhan perusahaan maka semakin besar kebutuhan dana untuk membiayai kesempatan investasi perusahaan (dalam hal ini pembiayaan untuk ekspansi perusahaan). Semakin besar kebutuhan akan pembiayaan ekspansi perusahaan maka akan semakin besar perusahaan untuk menahan laba perusahaan.

Tingkat Pertumbuhan $=\frac{\text { Total Aktiva } \mathrm{t}-\text { Total Aktiva } \mathrm{t}-1}{\text { Total Aktiva } \mathrm{t}-1} \times 100 \%$

Dimana:

Total Aktiva ${ }_{\mathrm{t}} \quad=$ Total Aktiva tahun berjalan

Total Aktiva $_{\mathrm{t}-1}=$ Total Aktiva tahun lalu

\section{Non-Debt Tax Shield}

Non - debt tax shield merupakan deduksi pajak untuk depresiasi dan tax credit investasi. Non-debt tax shield (NDTS) ini muncul karena perusahaan mengeluarkan biaya depresiasi sebagai dampak terhadap penggunaan aktiva terutama aktiva tetap. Keuntungan yang diperoleh perusahaan apabila menggunakan utang sebagai pendanaan untuk kegiatan investasi perusahaan akan berdampak terhadap penghematan pajak dan biaya bunga yang akan dibayarkan. Begitu juga dengan perusahaan yang mengeluarkan biaya depresiasi yang lebih besar, maka akan mendapatkan keuntungan pajak sebagai dampak dari biaya depresiasi yang dibayarkan. Bukti empiris menyatakan bahwa perusahaan yang non - debt tax shield yang lebih besar akan berdampak terhadap pengurangan utang yang akan dibayarkan.

Non-debt tax shield merupakan pembagian antara total biaya depresiasi dan amortisasi terhadap total aktiva yang dapat dirumuskan sebagai berikut:

Non - Debt Tax Shield $=\frac{\text { Total Biaya Depresiasi dan Amortisasi }}{\text { Total Aktiva }} \times 100 \%$

\section{Konsep Penelitian}

Nilai perusahaan sebagai variabel dependen yang dipengaruhi oleh variabel independen yaitu: profitabilitas, asset tangibility, tingkat pertumbuhan, ukuran perusahaan dan non-debt tax shield dan struktur modal sebagai variabel intervening.

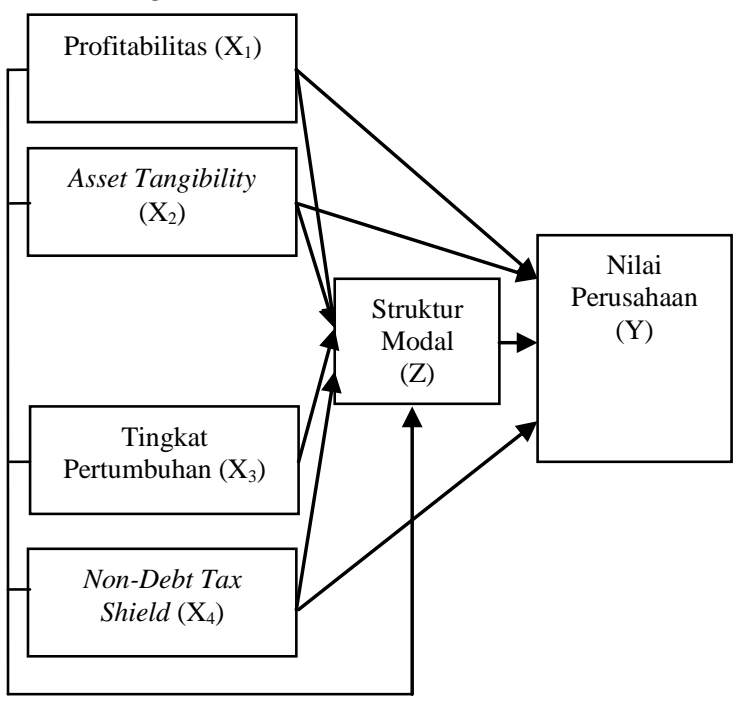

\section{METODE PENELITIAN}

Penelitian ini dilakukan di Bursa Efek masingmasing negara Asia Tenggara yang ada di Keuangan Commodity Exchange melalui media internet dengan situs https://sites.google.com/site/keuangancommodityex change/, serta situs-situs lain yang mendukung penelitian. Penelitian ini dilakukan dimulai dari bulan Maret 2018 sampai dengan selesai.

Adapun kriteria populasi dapat dijelaskan pada tabel 3.1 berikut ini : 


\begin{tabular}{|c|c|c|c|c|c|c|c|c|c|}
\hline \multicolumn{10}{|c|}{ Tabel 3.1 Kriteria Populasi Penelitian } \\
\hline No & Kategori & & & Jun & lah & erus & haan & & \\
\hline 1 & $\begin{array}{l}\text { Negara di kawasan Asia Tenggara yang } \\
\text { memiliki Bursa Efck di Keuangan Commodity } \\
\text { Exchage. }\end{array}$ & IDN & MAS & $\sin$ & THA & PHI & CAM & LAO & VIE \\
\hline 2 & 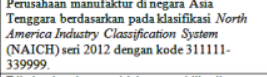 & 138 & 320 & 270 & 15 & 43 & 0 & 0 & 0 \\
\hline $3^{3}$ & $\begin{array}{l}\text { Dikclankikan karecna tidak mempubilikasikan } \\
\text { laporan keuangan secara lengkap selama } \\
\text { periode (2013-2015). }\end{array}$ & (8) & (181) & (204) & (2) & (21) & (0) & (0) & (0) \\
\hline $4^{4}$ & 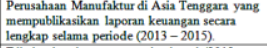 & 130 & 139 & 66 & 14 & 22 & 0 & 0 & 0 \\
\hline 5 & $\begin{array}{l}\text { Dikeluarkan karcena mengalami rugi (2013- } \\
\text { 2015) }\end{array}$ & (47) & (52) & $(42)$ & (0) & (10) & (0) & (0) & (0) \\
\hline 6 & $\begin{array}{l}\text { Dikcluarkan karena memiliki ckuitas negatif } \\
(2013-2015)\end{array}$ & (6) & (1) & (0) & (0) & (1) & (0) & (0) & (0) \\
\hline & $\begin{array}{l}\text { Jumbah Sampel } \\
\text { Toth Sampe| }\end{array}$ & 77 & 86 & 24 & 13 & 11 & 0 & 0 & 0 \\
\hline
\end{tabular}

Sumber:

https://sites.google.com/site/keuangancommodityex changel (data diolah 2018)

Penelitian ini menggunakan sampel jenuh (sensus) dengan menggunakan unit analisis data panel atau pooling data dengan periode 3 tahun yaitu dari 2013-2015 dan $\mathrm{N}=211$ perusahaan sehingga jumlah pengamatan sebanyak 633 Pengamatan.

\section{Uji Asumsi Klasik}

Uji Multikolinieritas, Uji Non-Autokorelasi dan Uji Heteroskedastisitas

\section{Metode Analisis Statistik Deskriptif Pengujian Hipotesis}

Selanjutnya untuk menguji hipotesis yang diajukan mengenai pengaruh variabel independen terhadap variabel dependen, maka digunakan analisis statistik Uji Statistik F, Uji Statistik t dan koefisien determinasi $\left(\mathrm{R}^{2}\right)$. Pengaruh variabel independen terhadap variabel dependen di uji dengan tingkat kepercayaan $95 \%$ atau signifikansinya $\alpha=5 \%$.

\section{Hasil Peneliitian}

Regresi Model 1

\begin{tabular}{|c|c|c|c|c|}
\hline \multicolumn{5}{|c|}{ Model Summary } \\
\hline Model & $\mathrm{R}$ & R Square & $\begin{array}{l}\text { Adjust } \\
\text { ed } R \\
\text { Square }\end{array}$ & $\begin{array}{l}\text { Std. Error of the } \\
\text { Estimate }\end{array}$ \\
\hline 1 & $\begin{array}{l}1 \\
9 \\
8 \\
a\end{array}$ & .039 & .033 & .73842 \\
\hline
\end{tabular}

a. Predictors: (Constant), Non-Debt Tax Shield, Tingkat Pertumbuhan, Profitabilitas, Asset Tangibility

\begin{tabular}{|c|c|c|c|c|c|}
\hline \multicolumn{6}{|c|}{ ANOVA $^{a}$} \\
\hline Model & $\begin{array}{l}\text { Sum of } \\
\text { Squares }\end{array}$ & df & $\begin{array}{l}\text { Mean } \\
\text { Square }\end{array}$ & $\mathrm{F}$ & Sig. \\
\hline Regression & 13.922 & 4 & 3.480 & 6.383 & $.000^{\mathrm{b}}$ \\
\hline Residual & 342.427 & 628 & .545 & & \\
\hline Total & 356.348 & 632 & & & \\
\hline
\end{tabular}

a. Dependent Variable: Struktur Modal

b. Predictors: (Constant), Non-Debt Tax Shield, Tingkat

Pertumbuhan, Profitabilitas, Asset Tangibility

\begin{tabular}{|c|c|c|c|c|c|c|}
\hline \multicolumn{7}{|c|}{ Coefficients $^{a}$} \\
\hline \multirow{2}{*}{\multicolumn{2}{|c|}{ Model }} & \multicolumn{2}{|c|}{$\begin{array}{l}\text { Unstandardized } \\
\text { Coefficients }\end{array}$} & \multirow{2}{*}{\begin{tabular}{|c|}
$\begin{array}{l}\text { Standardized } \\
\text { Coefficients }\end{array}$ \\
Beta
\end{tabular}} & \multirow[b]{2}{*}{$\mathrm{t}$} & \multirow{2}{*}{ Sig. } \\
\hline & & $B$ & $\begin{array}{l}\text { Std. } \\
\text { Error }\end{array}$ & & & \\
\hline \multirow{5}{*}{1} & (Constant) & .839 & .071 & & $\begin{array}{r}11.82 \\
1\end{array}$ & .000 \\
\hline & Profitabilitas & -1.413 & .367 & -.151 & -3.846 & .000 \\
\hline & $\begin{array}{l}\text { Asset } \\
\text { Tangibility }\end{array}$ & .176 & .169 & .043 & 1.043 & .297 \\
\hline & $\begin{array}{l}\text { Tingkat } \\
\text { Pertumbuhan }\end{array}$ & .698 & .249 & .110 & 2.800 & .005 \\
\hline & $\begin{array}{l}\text { Non-Debt } \\
\text { Tax Shield }\end{array}$ & -.009 & .979 & .000 & -.009 & .993 \\
\hline
\end{tabular}

Regresi Model 2

Model Summary

\begin{tabular}{|l|r|r|r|r|}
\hline Model & $\mathrm{R}$ & $\mathrm{R}$ Square & $\begin{array}{c}\text { Adjusted } \\
\text { R Square }\end{array}$ & $\begin{array}{c}\text { Std. Error of } \\
\text { the Estimate }\end{array}$ \\
\hline 1 & $.175^{\mathrm{a}}$ & .031 & .023 & 14.77996 \\
\hline
\end{tabular}

a. Predictors: (Constant), Struktur Modal, Non-Debt Tax Shield,

Tingkat Pertumbuhan, Profitabilitas, Asset Tangibility

ANOVA $^{a}$

\begin{tabular}{|c|c|c|c|c|c|}
\hline Model & $\begin{array}{c}\text { Sum } \\
\text { of Squares }\end{array}$ & $\mathrm{df}$ & $\begin{array}{c}\text { Mean } \\
\text { Square }\end{array}$ & $\mathrm{F}$ & Sig. \\
\hline Regression & 4321.591 & 5 & 864.318 & 3.957 & $.002^{D}$ \\
\hline Residual & 136966.347 & 627 & 218.447 & & \\
\hline Total & 141287.938 & 632 & & & \\
\hline
\end{tabular}

a. Dependent Variable: Nilai Perusahaan

b. Predictors: (Constant), Struktur Modal, Non-Debt Tax Shield,

Tingkat Pertumbuhan, Profitabilitas, Asset Tangibility

Coefficients $^{\mathrm{a}}$

\begin{tabular}{|c|c|c|c|c|c|}
\hline \multirow[t]{2}{*}{ Model } & \multicolumn{2}{|c|}{$\begin{array}{c}\text { Unstandardized } \\
\text { Coefficients }\end{array}$} & $\begin{array}{l}\text { Standardized } \\
\text { Coefficients }\end{array}$ & \multirow[t]{2}{*}{$\mathrm{t}$} & \multirow[t]{2}{*}{ Sig. } \\
\hline & B & $\begin{array}{l}\text { Std. } \\
\text { Error }\end{array}$ & Beta & & \\
\hline (Constant) & -1.053 & 1.570 & & -.671 & .503 \\
\hline Profitabilitas & 5.399 & 7.440 & .029 & .726 & .468 \\
\hline $\begin{array}{l}\text { Asset } \\
\text { Tangibility }\end{array}$ & $\begin{array}{r}11.31 \\
6\end{array}$ & 3.387 & .140 & 3.341 & .001 \\
\hline $\begin{array}{ll}1 & \text { Tingkat } \\
& \text { Pertumbuhan }\end{array}$ & $\begin{array}{r}13.27 \\
3\end{array}$ & 5.024 & .105 & 2.642 & .008 \\
\hline $\begin{array}{l}\text { Non-Debt } \\
\text { Tax Shield }\end{array}$ & -3.561 & $\begin{array}{r}19.58 \\
9\end{array}$ & -.008 & -.182 & .856 \\
\hline Struktur Modal & -.547 & .799 & -.027 & -.684 & .494 \\
\hline
\end{tabular}

a. Dependent Variable: Nilai Perusahaan

\section{PENUTUP}

\section{Kesimpulan}

1. Analisis pengaruh Profitabilitas,Asset Tangibility, Tingkat Pertumbuhan dan Nondebt Tax Shield terhadap Struktur Modal, dapat disimpulkan bahwa Profitabilitas dan Tingkat Pertumbuhan mempengaruhi Struktur Modal secara signifikan, sementara Asset Tangibility dan Nondebt Tax Shield tidak signifikan.

2. Asset Tangibility dan Tingkat Pertumbuhan mempengaruhi Nilai Perusahaan secara signifikan, sementara Profitabilitas dan Nondebt Tax Shield tidak signifikan.

3. Struktur Modal mempengaruhi Nilai Perusahaan tidak signifikan

4. Secara tidak langsung Nondebt Tax Shield melalui Struktur Modal mempunyai pengaruh 
signifikan terhadap Nilai Perusahaan, sementara Profitabilitas, Asset Tangibility, dan Tingkat Pertumbuhan tidak signifikan

5. Penelitian ini mendukung penelitian sebelumnya yaitu penelitian yang dilakukan oleh (Hamidy, 2014; Masidonda, 2013) yang menyimpulkan bahwa struktur modal berpengaruh positif terhadap nilai perusahaan.

\section{DAFTAR PUSTAKA}

Brigham, Eugene F. and L.C. Gapenski. 2006. Intermediate Financial Management. 7th edition. SeaHarbor Drive: The Dryden Press

Brigham, Eugene F. and Joel F. Houston. 2006. Dasar-Dasar Manajemen Keuangan, alih bahasa Ali Akbar Yulianto, Buku satu, Edisi sepuluh. Jakarta: PT. Salemba Empat.

Firnanti, Friska. 2011. Faktor-Faktor yang Mempengaruhi Struktur Modal Perusahaan Manufaktur di Bursa Efek Indonesia. Jurnal Bisnis dan Akuntansi. Vol. 13 No. 2: 119-128.

Hamidy, Rahman Rusdi. 2014. Pengaruh Struktur Modal Terhadap Nilai Perusahaan Dengan Profitabilitas Sebagai Variabel Intervening Pada Perusahaan Properti Dan Real Estate Di Bursa Efek Indonesia. Tesis. Program Studi Manajemen Program Pascasarjana Universitas Udayana. Denpasar.

Joni dan Lina. 2010. Faktor-faktor yang Mempengaruhi Struktur Modal. Jurnal Bisnis dan Akuntansi. Vol. 12 No. 2: 8196.

Mardiyati, Umi., Ahmad, Gatot Nazir dan Putri, Ria. 2012. Pengaruh Kebijakan Dividen, Kebijakan Hutang Dan Profitabilitas Terhadap Nilai Perusahaan Manufaktur Yang Terdaftar Di Bursa Efek Indonesia (BEI) Periode 2005- 2010. Jurnal Riset
Manajemen Sains Indonesia (JRMSI). Vol. 3 No. 1: 1-17

Masidonda, Jaelani La. 2013. Determinan Struktur Modal dan Dampak Struktur Modal terhadap Nilai Perusahaan (Studi pada Perusahaan Manufaktur di Bursa Efek Indonesia). Disertasi. Program Doktor Ilmu Manajemen Universitas Brawijaya. Malang.

Rakhimsyah, Leli Amnah dan Barbara, Gunawan. 2011. Pengaruh Keputusan Investasi, Keputusan Pendanaan, Kebijakan Dividen dan Tingkat Suku Bunga terhadap Nilai Perusahaan. Jurnal Investasi. Vol. 7 No. 1: 31-45.

Ross, A. S., Westerfield, R. W., and Jaffe, J. 2005. Corporate Finance. Seventh Edition, Boston: Mc Graw-Hill.

Silaban, Pasaman dan Siahaan, Rusliaman. 2011. Manajemen Keuangan: Teori dan Aplikasi. Edisi 2 Medan: Unibersitas HKBP Nommensen.

Suharli, Michell. 2005. Studi Empiris Terhadap Dua Faktor Yang Mempengaruhi Return Saham Pada Industri Food \& Beveranges Di Bursa Efek Jakarta. Jurnal Akuntansi \& Keuangan. Vol. 7 No. 2: 99-116.

Sujono. 2010. Determinan Struktur Modal, Inovasi dan Nilai Perusahaan (Studi pada Industri Manufaktur di Bursa Efek Indonesia). Disertasi. Program Doktor Ilmu Manajemen Universitas Brawijaya. Malang.

Sumiati. 2011. Kekuatan Pasar, Struktur Modal dan Nilai Perusahaan (Studi pada Perusahaan Manufaktur yang terdaftar di Bursa Efek Indonesia). Disertasi. Fakultas Ekonomi dan Bisnis Universitas Brawijaya. Malang.

Wild, John J., Subramanyam, K.R., Halsey, Robert F. 2005. Financial Statement Analysis- Analisis Laporan Keuangan. Edisi 8. Jakarta: Salemba Empat. 